\title{
APLIKASI PERPUSTAKAAN MENGGUNAKAN SMARTCARD RFID (Radio Frequency Identification)
}

\author{
Wagino \\ (wagino@fti.uniska-bjm.ac.id) \\ M. Edya Rosadi \\ (edya@fti.uniska-bjm.ac.id) \\ Arif Wahyudi \\ (arifwahyudi700@gmail.com)
}

\begin{abstract}
ABSTRAK
Semakin meningkatnya atau bertambahnya koleksi bahan pustaka di Badan Perpustakaan dan Arsip Daerah Provinsi Kalimantan Selatan atau yang sering di sebut (Bapustarda), kebutuhan informasi yang berkaitan dengan bahan pustaka yang ada, keterbatasan petugas pelayanan perpustakaan merupakan beberapa permasalahan yang seringkali timbul dalam pengelolaan perpustakaan. Tujuan penelitian ini adalah membuat aplikasi untuk menangani proses tersebut agar dapat meningkatkan pelayanan kepada para pengguna perpustakaan. Aplikasi perpustakaan ini, bisa dapat memaksimalkan pelayanan kepada pengguna perpustakaan dan juga meminimalkan kesalahan dalam pengolahan data. Sistem informasi perpustakaan dimulai dari pendataan anggota, pendataan buku, peminjaman buku, pengembalian buku, pemberian surat bebas perpustakaan dan pembuatan laporan meliputi laporan data anggota, laporan data buku, laporan peminjaman buku, laporan pengembalian buku serta laporan penerimaan denda. Adapun manfaat dari aplikasi perpustakaan ini sangat di harapkan dapat meningkatkan pelayanan perpustakaan dan membuat lancar proses administrasi menjadi lebih cepat dan akurat pada Badan Perpustakaan dan Arsip Daerah Provinsi Kalimantan Selatan atau yang sering di sebut (Bapustarda).
\end{abstract}

Kata Kunci : Sistem Informasi, Pelayanan, RFID, Perpustakaan.

\section{PENDAHULUAN}

Badan Perpustakaan dan Arsip Daerah Provinsi Kalimantan Selatan atau yang sering di sebut (Bapustarda) adalah salah satu instansi pemerintahan yang bergerak dibidang penyedia sarana baca, yang peranannya sangatlah penting untuk masyarakat. Misalnya pada Badan Perpustakaan dan Arsip Daerah Provinsi Kalimantan Selatan (Bapustarda), pembuatan sistem informasi teknologi terkini sangat diperlukan untuk mempelajari proses pendataan Anggota, maupun pendataan buku, serta mempermudah proses transaksi peminjaman muapun pengembalian buku. Diharapkan dengan aplikasi ini dapat mempermudah juga mempercepat pengambilan data yang diinginkan. Dengan adanya aplikasi ini diharapkan semua proses pendaftaran dan juga proses transaksi dapat menjadi lebih mudah dikontrol juga ditingkatkan kualitasnya.

Aplikasi yang akan dibuat meliputi pendaftaran anggota, pendataan buku-buku dan pendataan semua transaksi, antara lain transaksi peminjaman dan pengembalian buku. Aplikasi ini dilengkapi proses simpan, tambah dan menghapus data dari inputan dan juga mengedit data yang di hendaki, pencarian, dan dilengkapi juga laporan dari masing-masing pencarian serta back up dan restore data seluruh data seluruh transaksi peminjaman, dan pengembalian buku. Fasilitas untuk mencetak laporan dari data-data seluruh 
transaksi sangatlah di perlukan karena sebagai bahan laporan pada kepala kantor.

Peran utama dari aplikasi ini yaitu menampung data-data anggota, buku, maupun data seluruh transaksi, sehingga mempermudah pencarian data berdasarkan yang diinginkan dengan cepat, tepat dan akurat.

\section{RUMUSAN MASALAH}

Rumusan masalah pada penelitian ini adalah Bagaimana Membuat aplikasi Perpustakaan Menggunakan SmartCard RFID (Radio Frequency Indentification) menggunakan bahasa pemrogramman Delphi.

\section{TUJUAN PENELITIAN}

Tujuan penelitian ini yaitu membuat aplikasi Perpustakaan Menggunakan SmartCard RFID (Radio Frequency Indentification) Pada Badan Perpustakaan dan Arsip Daerah Provinsi Kalimantan Selatan (Bapustarda).

\section{TARGET LUARAN DAN MANFAAT PENELITIAN}

Target Luaran yaitu Publikasi ilmiah dalam jurnal lokal yang mempunyai ISSN atau jurnal nasional terakreditasi seperti jurnal Al 'Ulum Universitas Islam Kalimantan (UNISKA)

Manfaat dari penelitian ini yaitu mempermudah pekerjaan pengelola Badan Perpustakaan dan Arsip Daerah Provinsi Kalimantan Selatan (Bapustarda) dalam proses pendataan Anggota, maupun pendataan buku, serta mempermudah proses transaksi peminjaman dan pengembalian buku, sistem informasi perpustakaan lebih akurat dan menggunakan komputerisasi secara otomatis.

\section{METODE PENELITIAN}

Metode penelitian yang dilakukan dalam penelitian ini, dengan tahapan penelitian seperti berikut:

\section{Wawancara (Interview)}

Yaitu teknik pengumpulan data dengan cara mewawancarai langsung pihak-pihak yang terkait dalam penelitian ini seperti pada Badan Perpustakaan dan Arsip Daerah Provinsi Kalimantan Selatan.

\section{Observasi (Field researce)}

Observasi yang dilakukan adalah dengan cara mengamati secara langsung kegiatan-kegiatan di Badan Perpustakaan Dan Arsip Daerah Provinsi Kalimantan Selatan.

\section{Kepustakaan (Library researce)}

Mengumpulkan data dengan membaca buku-buku yang relevan untuk membantu di dalam menyelesaikan dan juga untuk melengkapi data yang berhubungan dengan masalah yang ada di Badan Perpustakaan Dan Arsip Daerah Provinsi Kalimantan Selatan.

\section{Lokasi Penelitian}

Lokasi pengambilan data di Badan Perpustakaan dan Arsip Daerah Provinsi Kalimantan Selatan (Bapustarda).

\section{ANALISIS HASIL DAN PEMBAHASAN \\ 1. Evaluasi Sistem Yang Sedang Berjalan \\ Dalam Pelaksanaan Wawancara} (Interview) kepada petugas Badan Perpustakaan dan Arsip Daerah Provinsi Kalimantan Selatan pengolahan data sudah menggunakan aplikasi Web dan Database Mysql Xampp. Disamping itu media penyimpanan masih ada menggunakan buku induk, tidak disimpan didalam database.

\section{Usulan Sistem Baru}

Adapun usulan sistem baru yang diusulkan untuk meningkatkan dan memperbaharui sistem yang sedang berjalan, yaitu dengan merancang dan membuat system baru berbasis computer dan mempermudah dalam proses pendataan 
Anggota, maupun pendataan buku, serta mempermudah proses transaksi peminjaman dan pengembalian buku Pada Badan Perpustakaan dan Arsip Daerah Provinsi Kalimantan Selatan.

\section{Gambaran Usulan Sistem}

Sistem yang di usulkan dalam perancangan sistem ini berbasis desktop menggunakan bahasa pemograman Delphi 7.0 dan menggunakan database mysql Xampp dan menggunakan SmartCard RFID untuk memudahkan pengolahan dalam proses pendataan Anggota, maupun pendataan buku, serta mempermudah proses transaksi peminjaman dan pengembalian buku Badan Perpustakaan dan Arsip Daerah Provinsi Kalimantan Selatan. sistem informasi perpustakaan lebih akurat dan menggunakan komputerisasi secara otomatis, Meningkatkan efisiensi kerja berkenaan dengan pengolahan data Anggota, maupun pendataan buku dan Memudahkan dan mempercepat proses transaksi peminjaman dan pengembalian buku dalam hal pencarian data yang diperlukan dan meningkatkan keamanan data yang terjamin.

Sistem informasi yang akan dibuat akan didasarkan pada proses yang sudah berjalan, dimana sistem usulan ini hanya memindahkan proses manual menjadi terkomputerisasi serta menambahkan proses inputan pada beberapa bagian proses tertentu

\section{Perancangan Output Sistem Diagram Konteks}

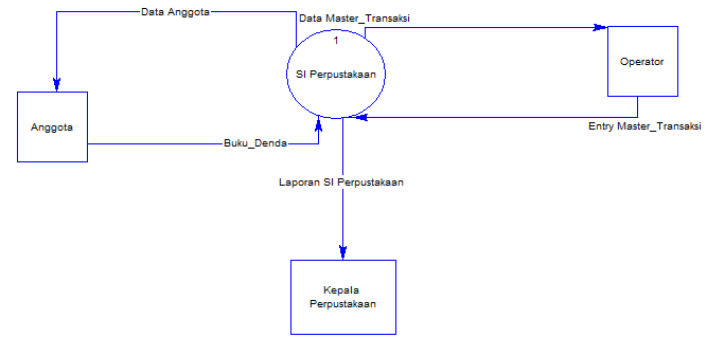

Data Flow Diagram

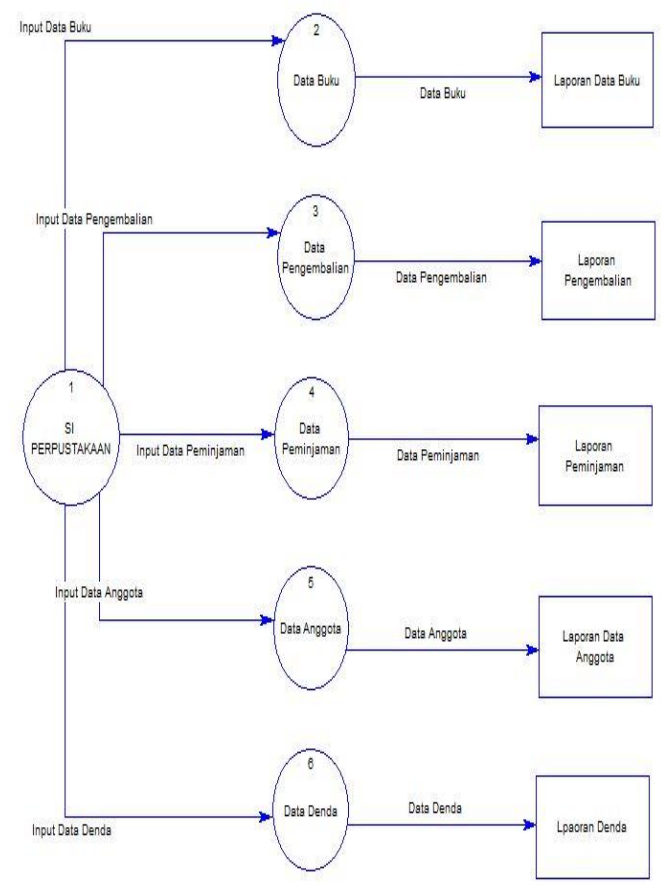

Relasi Tabel

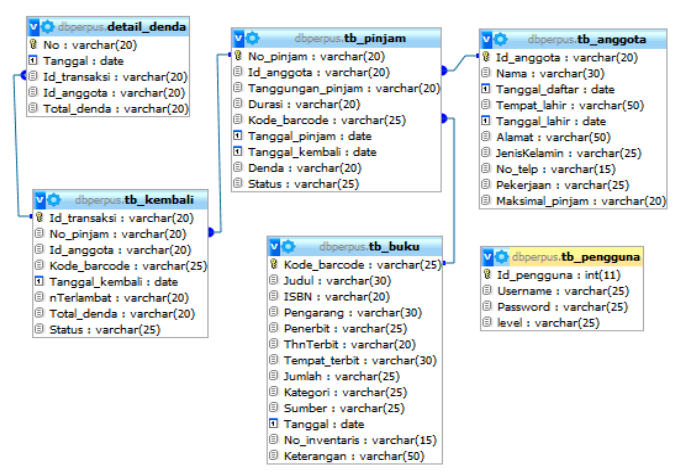

Halaman Utama

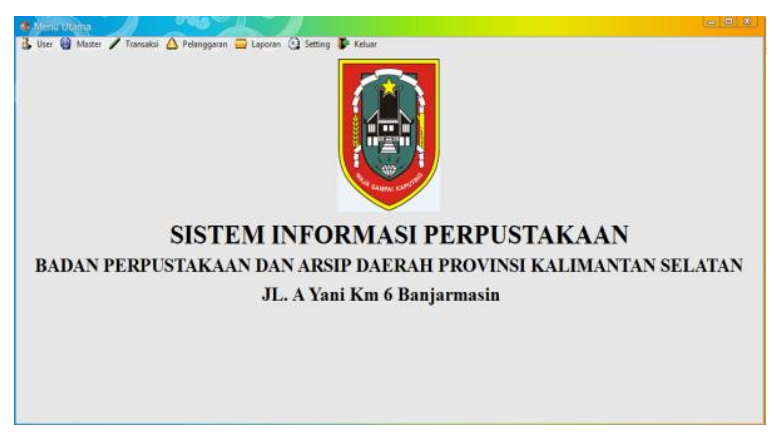




\section{Entry Anggota}

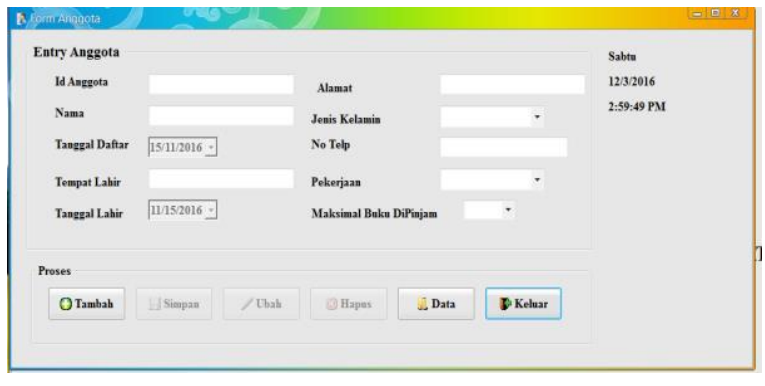

\section{Entry Katalog Buku}

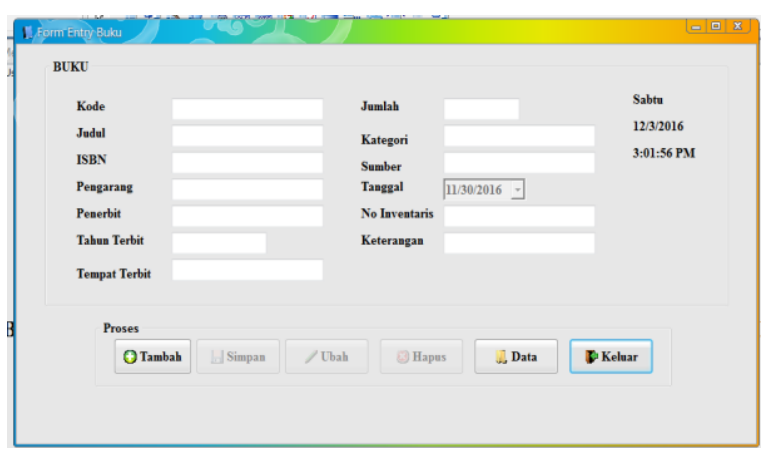

Output Data Anggota

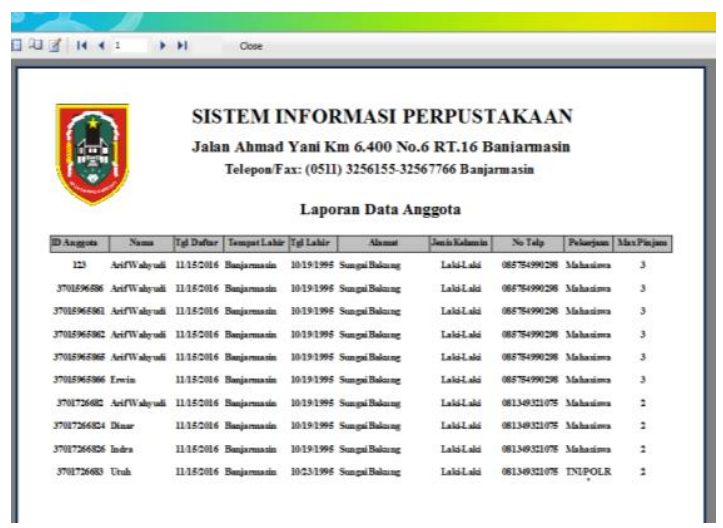

\section{Output Data Katalog Buku}

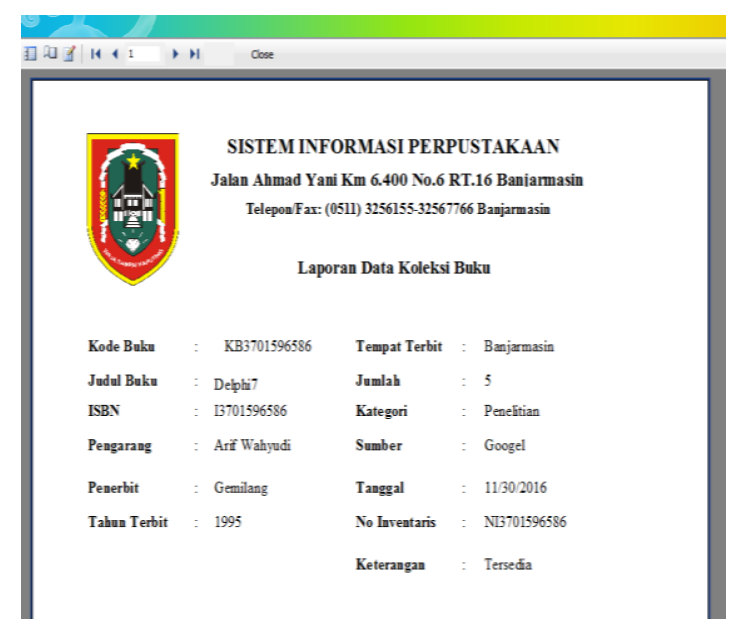

\section{PENUTUP}

Kesimpulan

Berdasarkan hasil penelitian dan pembahasan dalam penelitian ini, Maka dapat disimpulkan :

1. Sistem informasi yang sudah terkomputerisasi dapat memberikan kemudahan serta mempercepat pengolahan dalam pembuatan laporan dan pencarian serta mempermudah dalam proses pendataan Anggota, maupun pendataan buku, serta mempermudah proses transaksi peminjaman dan pengembalian buku pada Pada Badan Perpustakaan dan Arsip Daerah Provinsi Kalimantan Selatan.

2. Informasi output data yang di sajikan berupa laporan menjadi lebih akurat dan tingkat ketelitian lebih tinggi, sehingga kemungkinan kesalahan sangat kecil dan data media penyimpanan data Anggota, buku serta transaksi peminjaman dan pengembalian buku Pada Badan Perpustakaan dan Arsip Daerah Provinsi Kalimantan Selatan tidak lagi menggunakan buku induk disimpan didalam database.

3. Sistem informasi yang sudah terkomputerisasi dapat memberikan keamanan dalam penyimpanan data sehingga tidak perlu khawatir data menjadi rusak atau hilang.

\section{Saran}

Penelitian ini dapat dikembangkan menjadi sistem informasi yang berbasis web dan android, sehingga dapat di akses dari mana saja selama masih dalam cakupan internet.

Untuk penelitian selanjutnya bisa dikembangkan lagi, misalkan membuatkan fitur backup data secara otomatis. 


\section{DAFTAR PUSTAKA}

[1] Mudjihartono, P., Suyoto, Maryono, 2010, Analisis dan perancangan Sistem Informasi Manajemen Aset TIK, Studi Kasus: ASMI Santa Maria Yogyakarta, Jurnal Buana Informatika, Volume 1 Nomor 2 - Juli 2010, Universitas Atma Jaya, Yogyakarta.

[2] Indriyawan, Eko. 2005. Pemograman Database menggunakan Delphi dan MySQL server, Andi, Yogyakarta.

[3] Mita, 2010, Pengenalan Borland Delphi 7, Semarang.

[4] Burch, J.G., System Analysis, Design, and Implementation, Boyd \& Frasher Publishing Company, 1992.

[5] Tarigan, Josep R dan Suparmoko (1999), Metode Pengumpulan Data Edisi 1 (Untuk llmu-ilmu sosial dan ekonomi), BPFE, Yogyakarta.

[6] Usman, D. (2011, January 12). Printer dan Teknologi Printing. Retrieved September 24, 2012, from David Usman:

[7] Kristanto, A., 2004, Rekayasa Perangkat Lunak (Konsep Dasar), Penerbit Gava Media, Yogyakarta. 